\title{
The Audibility and Lowermost Altitude of the Aurora Polaris.
}

\author{
By Prof. S. Chapman, F.R.S.
}

THE aurora polaris, after long study, remains 1 in many respects mysterious; of late years, however, scientific opinion has been nearly unanimous in regard to its height in the atmosphere, locating it at about 100 kilometres and above. Størmer has found trustworthy evidence, in a few cases, of its occurrence so low as $80 \mathrm{~km}$. Its upward extent is very variable, but at times it rises to a height of $800 \mathrm{~km}$. These very high auroræ seem to occur exclusively in the part of the atmosphere which, though viewed from stations in the night hemisphere, is itself still illuminated by the sun's rays ; no very likely explanation of this remarkable fact has yet been proposed.

The gradual accumulation of trustworthy photographic measures of the height of auroræ, observed simultaneously from two or more stations, since Størmer introduced his now well-known methods, has steadily added strength to this conviction. Yet from early times to the present day there have been occasional reports of auroræ situated at much lower heights, so as to be visible between the beholder and high land at no great distance. Likewise there have been many accounts of auroræ having been heard, a thing scarcely to be credited if they are located at heights of $80 \mathrm{~km}$. or more. Both kinds of observation have in general been viewed with suspicion.

In 1918 , Dr. G. C. Simpson, in a letter to NaturE (Sept. 12 ; p. 24), referred to the question of low auroræ, and recounted three cases that came under his notice during the 1910-12 Scott antarctic expedition: he had asked his colleagues to direct his attention to any auroræ observed by them at low altitudes; in each instance he concluded, on personally viewing the aurora, that its situation below the clouds, or between the camp and neighbouring mountains, was only apparent-that chance circumstances combined to produce an optical illusion, distinguishable as such only on the closest scrutiny. Indeed, on one of the three occasions a majority of his colleagues were not convinced by him that the appearance was only illusory.

Such an examination, by a first-rate observer, of observations that were apparently anomalous, and contradictory of the results uniformly given by the best methods of observation, was of great value. Since it dealt only with a few particular cases, it could not dispose of the possibility that in other cases the appearance of low auroræ was real and not counterfeit; yet it certainly showed that now and then appearances were very likely to deceive, and emphasised the need for caution in accepting reports even from the most trustworthy and convinced observers.

The discussion has recently been carried to a further stage through the zeal of Mr. J. Halvor Johnson, of San Mateo, California, who for many years lived near, and beyond, the Arctic circle, and witnessed many auroræ. During these years he observed, once only, in Alaska, in 1901, an unmistakably low aurora, which was visible between himself and a mountain about half a mile distant, rising to about 1200 feet above his own level. Moreover, on this and but one other occasion he heard sounds accompanying the aurora. At the time he had read little with reference to the aurora, and was ignorant of the prevailing opinion that the aurora is confined to the upper atmosphere. In recent years his conviction, based on his own experience, that this opinion is not true in all cases, has led him to seek further evidence on the point, from other observers. From few parts of the world is such information likely to be more readily available than from North America-Alaska and northern Canada. Here, owing to the inclination of the earth's magnetic axis in this direction, a long stretch of the zone of maximum auroral frequency passes overland, in a region which, though inhospitable and sparsely populated, is yet inhabited by a large number (in the aggregate) of civilised men, including some, such as surveyors, and occasional professional men in small townships, of considerable intelligence and education. Mr. Johnson, recognising that low-level auroræ are at least rare, and apparently have not occurred at times and places where arrangements for measuring their altitude were available, in 1928 addressed a letter to each of the newspapers published in Alaska and the British Yukon Territory, seeking information in regard to auroral displays.

In this letter Mr. Johnson directed particular attention to the question of low altitude and sound, stating the position very fairly: "much respectable testimony", on one hand, in favour of occasional sounds, and " exceedingly rare " close approaches of the aurora; and, on the other hand, the prevailing scientific disbelief, and the statements of many men who have travelled extensively in the arctic regions, that they have never heard auroral sounds. He did not mention his own experience or conviction. His letter was given a prominent place in the newspapers, and produced many replies; some of these he followed up by further direct correspondence. He has lately published a small pamphlet "Concerning the Aurora Borealis" (29 pages ; privately printed, at the Gazette Press, Berkeley, California, 1930), giving a selection of the letters (17 pages), accompanied by an introduction and brief historical aecount of the subject (11 pages). The writers of the letters include men from various stations in life, from " the simple pioneer and prospector, whose spirit of helpfulness outweighed his diffidence in writing, to the professional man of disciplined observational training ".

This inquiry is in some respects similar to one made by Sophus Tromholt in Norway in 1885: Tromholt wrote in NaTuRE (Sept. 24, 1885, vol. 32, p. 499) that up-to-date, out of 103 replies bearing on the question of auroral sounds, 53 were from

No. 3201, VoL. 127] 
writers who had personally heard such sounds, while a further 39 cited the testimony of others to the same effect; the remaining 21 declared they had never heard the sounds, or knew nothing of them. It may be recalled also that in NATURE, Jan. 8, 1927, vol. 119, p. 45, Prof. Størmer reported that on Oct. 15, 1926, H. S. Jelstrup and an assistant, at the observatory near Oslo, both heard auroral sounds during ten minutes which they were able to spend in the open watching the aurora, before continuing their observations; the sound was a very curious faint whistle, increasing and decreasing, seeming to follow exactly the vibrations of the aurora. Unfortunately, Størmer had no successful photographs of the aurora during the period in question.

Mr. Johnson's pamphlet contains letters from twenty persons. One of them does not refer to the two points here under discussion. Seventeen testify to having heard sounds accompanying auroræ, and some cite one or more friends who can bear similar testimony; sixteen state that they have seen auroræ coming close to the ground, and, of these, twelve assert that they have seen the light against a background of mountains or other objects near the ground. All these letters appear to be written in perfect good faith. Several of the writers who have heard auroral sounds describe them as fairly frequent; others have heard them only on one or a very few occasions in many years.

The sounds are variously described as " a swishing or rustle, like that of a silken skirt moving back and forth, . . . very low, but yet plainly discernible"; like those "that accompany small static discharges " ; like the sound made when " a couple of slices of good fat bacon are dropped into a red-hot pan"; "they may attain a loudness com. parable to that emitted by a high-tension electric current when charging a set of horn-gap lightning arresters"; "quite audible swishing, crackling, rustling sounds"; " a crackling so fine that it resembled a hiss" ; sounds " similar to escaping steam, or air escaping from a tire" ; " much like the swinging of an air hose with escaping air"; "the noise of swishing similar to a lash of a whip being drawn through the air" ; sounds "likened to a flock of birds flying close to one's head"; " not musical, it was a distinct tearing, ripping sound as when thin muslin is ripped or torn apart". One man at sea, in an open boat with four natives, on Oct. 11, 1893, heard " the most fearful whizzling and crackling sounds, sounding at times as if thousands of firearms were fired within short distance" ; at the time there was " no wind and no clouds". Another writer mentions "loud reports similar to rifle cracks", "the air was still and the aurora was just above the tops of the birches" ; the few loud reports were followed by much crackling.

Some of the accounts of low auroræ seen between the observer and terrestrial objects are very striking and circumstantial. One writer states that he and his party (members of a government radio station, in the winter of 1917-18) were enveloped in "a light mist or fog-like substance in the aurora " ; a hand extended could be seen as if in a coloured fog, and a kaleidoscope of colours was visible between the hand and the body. It was impossible to feel this visible fog or mist, and there was no dampness. By stooping close to the ground it was possible to see under this light, which did not go below four feet from the ground. The low-hung aurora lasted fifteen minutes, while great streaks and shafts of light came and went in the heavens. The occasion was unique in the writer's experience.

Another writer, during a brilliant auroral display, saw the light "play" down between himself and a steep glacial deposit bank about 125 feet away; he "stepped right into the aurora". Another saw an aurora between himself and a ten-foot bank not more than one half-mile away; there was "immense light", " on the very surface", and a shaft of light shot up to an immense height. Another in 1915 saw the familiar landscape " beautified by changing coloured lights which came and went rapidly, now bathing us, now withdrawing with a swish to a height of a mile or so" ; "it came down in streamers, or again as a fog (only much faster than fogs come, only a matter of seconds)" ; "we saw the tree trunks through the aurora", the colours being mostly, though not wholly, greens.

These letters make it difficult to deny that auroræ occur, very rarely, quite near the earth, and are sometimes accompanied by noises. Almost all the reports come from a belt of country about three hundred miles wide, lying roughly along the auroral zone; the belt includes the Klondike region, where is situated the township of Dawson, with a population of several thousand; several reports come from this neighbourhood. The only other places along the auroral zone, likely to afford such favourable fields of inquiry, appear to be near Churchill, on Hudson Bay; the extreme south of Greenland; Iceland and the most northerly part of Norway.

Since very low auroræ seem to be very rare and to be confined to localities near the auroral zone, it is perhaps not surprising that Størmer, Vegard, and Krogness should have observed no such case, or that the Polar Year (1882-83) failed to provide evidence establishing their existence; with the better organisation of auroral observation which it is hoped to achieve during the proposed new Polar Year (1932-33), there is more chance that opportunities of critical examination of these appearances will occur.

These low auroræ must obviously be very different in character from those observed in the upper atmosphere, though connected with them. Inability to understand their physical nature is not a sufficient ground, in the present state of knowledge, for rejecting the possibility of such occur. rences; such an attitude would, for example, forbid acceptance of the reality of globular lightning. The observations cited by Mr. Johnson constitute at least a case for active further inquiry, and render it highly desirable that auroral investigation near the auroral zone should include not only visual and photographic observations, but also atmospheric electric registration at a well-equipped observatory.

No. 3201, VoL. 127] 